\title{
The politics of tourism development: a case of dual governance in Tobago
}

\author{
Michelle T. McLeod*
}

School of Services Management,

Bournemouth University, Talbot Campus, Fern Barrow,

Poole, Dorset BH12 5BB, UK

Fax: +44 (0)1202 515707

E-mail:mmcleod@bournemouth.ac.uk

${ }^{*}$ Corresponding author

\section{David Airey}

Faculty of Management and Law,

University of Surrey,

Guildford, Surrey GU2 7XH, UK

Fax:+44 (0)1483686301Ｅ-mail: D.Airey@surrey.ac.uk

\begin{abstract}
The purpose of this paper is to report on an exploratory study of the role that tourism policy plays in influencing tourism development. The research is based on two questions: How does tourism policy influence tourism development in the small twin-island state of Trinidad and Tobago? and How does an arrangement of dual governance in a small twin-island state promote tourism development? The exploration demonstrates that tourism development in the context of Tobago, the smaller of the two islands, has been slowed as a result of dual governance and hence dual policy arrangements.
\end{abstract}

Keywords: Trinidad and Tobago; Tobago House of Assembly; tourism policy; tourism development; politics and governance; public policy; twin-island state; Caribbean tourism.

Reference to this paper should be made as follows: McLeod, M.T. and Airey, D. (200x) 'The politics of tourism development: a case of dual governance in Tobago', Int. J. Tourism Policy, Vol. x, No. x, pp.xxx-xxx.

Biographical notes: Michelle McLeod is a Postgraduate Research student at Bournemouth University. Her research interests include tourism policy, tourism development, governance, tourism networks and knowledge management.

David Airey is Pro-Vice-Chancellor and Professor of Tourism Management at the University of Surrey. He has been involved in tourism education and research for 35 years working in academia, with government and with the European Commission. He has particular interest in tourism education, tourism policy and organisation and tourism economics. 


\section{Introduction}

This paper presents an exploration of the influence of the government's tourism policy on the development of tourism in the small island of Tobago within the twin-island state of Trinidad and Tobago. The study particularly looks at how Tobago's tourism industry has developed through a dual governance arrangement with a central government based in Trinidad coupled with the Tobago House of Assembly (THA), a body corporate, governing Tobago. Tourism policy may be viewed as an outcome of political forces designed to bring about certain changes in the tourism destination. Bearing this in mind, a dual governance arrangement effectively means that tourism policy formulation and implementation is an activity of two governments seeking to influence tourism development. As a result, based on a framework of dual governance, the influences on tourism development potentially leads to conflict rather than collaboration, particularly if the two governments are of differing ideological positions. In such an environment, the development of the tourism industry is most likely to be constrained.

The discussion of dual governance is important and relevant to our knowledge of the politics of tourism development. The paper begins by presenting a literature review of public policy, tourism policy and its links to tourism development and provides the foundation for examining the research questions. The research study examines tourism development and seeks an explanation for tourism policy influencing tourism development by using a case study approach. The island of Tobago, which is the smaller island within the twin-island state, was selected since it provides an opportunity to examine the workings of central and sub-national government in developing a tourism industry. Interview data were collected and analysed by abstracting core thematic content. The main finding is that tourism policy that is made in a framework of dual governance does not permit the most effective development of tourism. Based on this, a recommendation is made for a divergence of tourism policy within a framework of two governments. Divergence of tourism policy means separate tourism formulation and implementation activity by the respective governments of each island.

\section{Literature review}

Public policy determination is not an exact science and is spread across several government institutions (Hall, 1994; Hall and Jenkins, 1995; Pearce, 1996; Church et al., 2000; Tyler and Dinan, 2001; Kerr, 2003; Kerr et al., 2001). According to Kerr (2003), public policy determination is the focal point of government activity. The activity of public policy comes from a multiplicity of interests and is based on achieving specified objectives, which are representative of value choices (Hall and Jenkins, 1995). These choices are made by government depending on the political, economic and constitutional system (Mill and Morrison, 1985) and ideological preferences (Matthews and Ritcher, 1991). Cooper et al. (1998) argue that public policy relating to tourism depends on the significance of the tourism industry to a country's economy. Chambers and Airey (2001, p.117) examine the role of public policy with a study of the impact of two divergent governmental public policy positions on the development of tourism on the island of Jamaica. As such, differing ideological positions, one based on socialist views and the other on capitalism affected the rate of tourism development on the island. They suggest, "tourism public policies are strongly influenced by the ideological thrust of 
the governing political parties". Generally, public policy cannot be separated from party politics (Hall and Jenkins, 1995). In other words, a relationship exists among the concepts of ideology, public policy, tourism policy and tourism development.

Ritchie and Crouch define tourism policy as

\begin{abstract}
"a set of regulations, rules, guidelines, directives and development/promotion objectives and strategies that provide a framework within which the collective and individual decisions directly affecting tourism development and the daily activities within a destination are taken." (Ritchie and Crouch, 2003, p.148)
\end{abstract}

Jenkins (1991) argues for a framework of tourism policy to facilitate tourism development. Such a framework outlines whether the driver of tourism is the public or private sector, the focus is international or domestic tourism, the scale of tourism development and whether integrated or enclave tourism. For instance, if the guideline is one of community-based tourism, then small tourist establishments owned by locals will be encouraged. As opposed to this, resort-based tourism may mean that enclave properties, which are largely foreign owned, emerge (Pearce, 1989; Sharpley and Telfer, 2002). Tourism policy will inevitably influence tourism development through a process. Hall (1994) argues that the tourism policy process is based on the type of government, its political will to develop tourism, the structure of tourism organisations and the stage of the development of the tourism industry. Dredge and Jenkins (2003a, p.386) concur with Hall's (1994) idea that there are forces that influence the policy process and argue "globalizing forces have also had significant impacts on tourism policy-making". For example, Curtin and Busby (1999) examine the influence of international tour operators. The complexity of interests has resulted in a search for clarity on issues relating to tourism public policy. Nonetheless, tourism development is the result of a framework of tourism policies formulated through stakeholder buy-in (Edgell, 1999; Bramwell and Sharman, 1999; Sautter and Leisen, 1999).

The role of government is critical in managing the public policy process. Kerr (2003) argues that industry cannot survive without government since government has the necessary legitimate power to provide the political stability, social infrastructure, security, and the legal and financial framework to smoothen the progress and development of tourism. Based on the complexity of interests in the policy process and the need for governmental control, it is understood that the institutional framework to formulate and implement tourism policy is a significant part of the tourism development process. It is perhaps the complexity of the policy process that has resulted in the emergence of local collaborative policymaking (Bramwell and Sharman, 1999). In addition, another level of government is sometimes necessary when national government does not allocate more of the scarce resources to a particular locality (Richter, 1985). On the other hand, there are challenges with creating another level of government. Dredge and Jenkins (2003b, p.415) highlight this in the case of tourism in Australia, "overlapping jurisdictions, multiple accountabilities and countervailing power are generally seen to impede effective tourism policy making". Thus, a clearly defined tourism institutional framework with stated roles and responsibilities for formulating and implementing tourism policy (Jordan, 2007) is a requirement for tourism development. Once the institutional framework is devised, then formulated tourism policies can be implemented. One such specific tourism policy relates to planning for tourism development. The economic, socio-cultural and environmental impacts of tourism development necessitate planning (Gunn, 1988; Hall, 2000). Additionally, tourism policy 
formulation and implementation may also be influenced by a country's geo-political framework. Weaver (1998) and Jordan (2007) argue that within the context of a twin-island state, core-periphery relationships can influence the present state of affairs.

\section{Tobago}

Trinidad and Tobago is the southernmost country of the Caribbean archipelago. Tobago is the smaller of the two islands in the twin-island state of Trinidad and Tobago. Both islands were joined politically in 1889 by Great Britain. After the country's independence in 1962, the governance of Tobago became the responsibility of the Tobago House of Assembly in 1980. The island's terrain comprising 116 square miles is made up of several hills and valleys with many natural bays and sandy deposits along the coastline. In terms of tourism, Tobago has the potential to develop as a successful tourism destination. As the winner of several eco-tourism awards, the island's rich green vegetation, coral reefs, beaches and picturesque landscape are world renowned. In 2003, Tobago received 67,240 stay-over visitors and 16,733 cruise visitors (DOT, 2005). The majority of visitors came for leisure purposes and stayed on average eight days. Average visitor expenditure was US\$ 530 in 2002 per visit. During that same period, the number of accommodation rooms was 2,634. The Tobago accommodation sector comprises largely small properties, though there are five properties with more than 100 rooms. The main arm of the THA, which implements tourism policy on the island, is the Department of Tourism.

Figure 1 shows growth in tourist arrivals for over 50 years, revealing an erratic pattern. There is evidence of strong growth over the periods 1995-1998 and also 2002-2004. Butler's (1980) involvement stage aptly describes the present state of tourist development in Tobago, although based on arrivals the island has approached the beginning of the development phase. There is largely local involvement in the industry, including the Tobago Hilton, the island's international flagship hotel. A local-based pattern of ownership in Trinidad and Tobago was previously noted by Weaver (1998, p.300) as an outcome of a policy of nationalisation. There are several local tourism and hospitality associations, which participate in tourism consultation processes and a tourism and hospitality training institution was established in 1997.

Figure 2 shows a comparative period of about 20 years of visitor arrivals to three Caribbean countries. Both Barbados and St. Lucia receive more visitors. The emergence of Tobago's tourism industry is evidenced by an increasing number of hotel projects putting it on a similar development path to that of St. Lucia and Barbados, but it is still well behind these competitors in visitor numbers.

Evidence suggests that attempts were made to formulate tourism policy for Trinidad and Tobago, starting in 1988 by the Trinidad and Tobago Tourism Development Authority (TDA), which is now defunct. The overarching policy for tourism development at that time as stated by the TDA $(1988$, p.4) was that tourism development would focus on cultural heritage, natural resources and history and not merely sea, sun and sand. Trinidad and Tobago also completed a Tourism Master Plan in 1995, but more than ten years later, this Master Plan is still to be implemented and a written policy to be devised. 
Figure 1 Tobago visitor arrivals (000) from 1946 to 2004

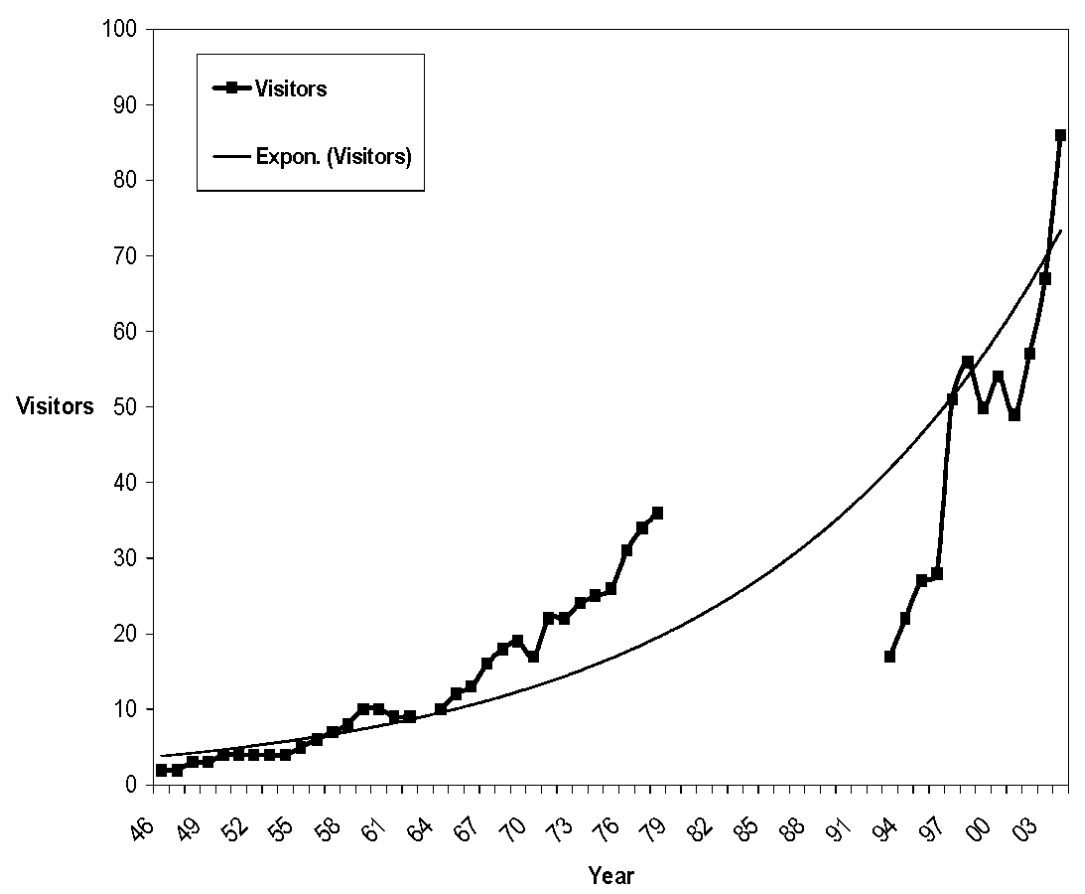

Tobago specific data was not available for the period 1980-1992.

Source: Weaver (1981) and CSO (2005)

Figure 2 Comparison of Caribbean destinations visitor arrivals 1986-2004

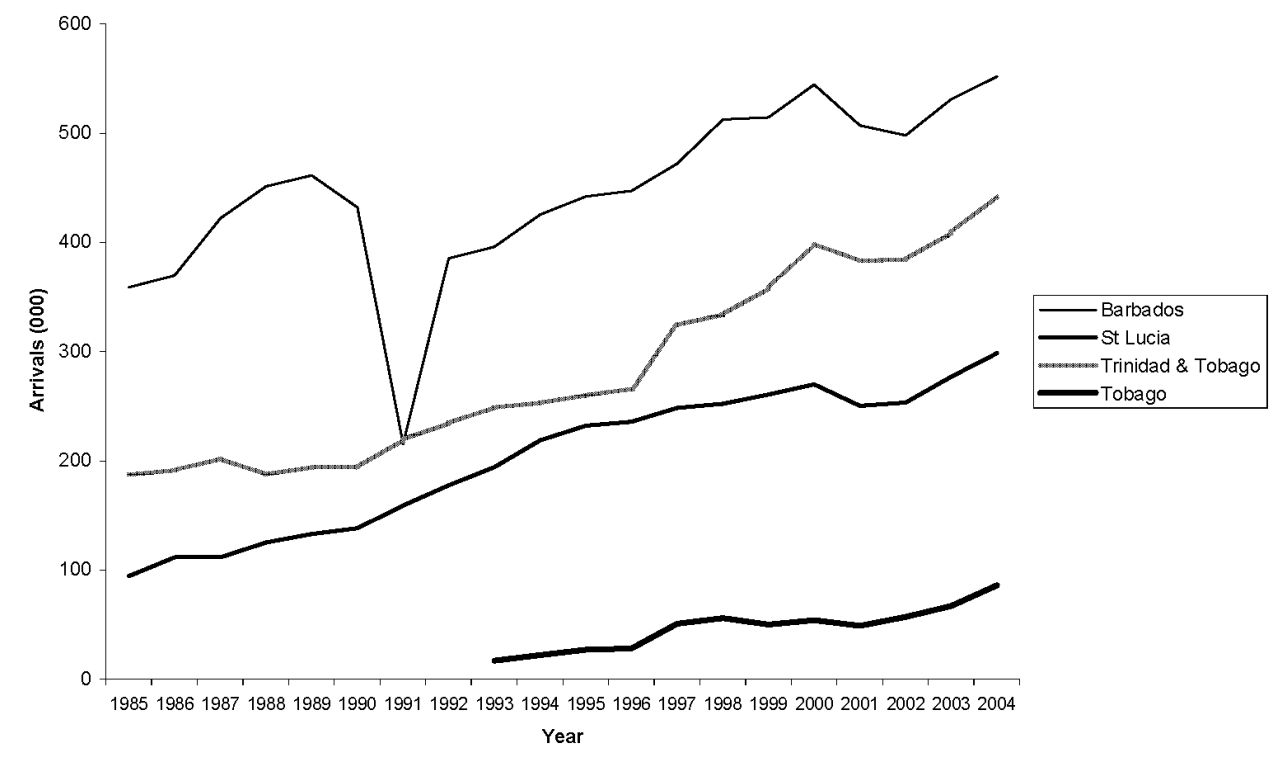

Tobago data only available from 1993.

Source: CTO (2005) 
Herein lies the role of the Tobago House of Assembly. The establishment of the Tobago House of Assembly (THA) in 1980 may be viewed as having been a milestone for the formulation and implementation of a Tobago public policy, including tourism policy. Nevertheless, it was only with the passing of the revised Tobago House of Assembly Act, in 1996, that tourism policy formulation obtained legal authority. The 1996 Act's Fifth Schedule, Item Six states that tourism is an area of the THA's responsibility. Even given legal authority, there is still conflict. According to Weaver

\begin{abstract}
"Since various Trinidad-based ministries and agencies will still thus maintain some de facto and de jure influence over tourism in Tobago, it appears as if the intended emergence of the THA as the main policy body for Tobagonian tourism may complicate rather than expedite the development of sector, which has been plagued with a reputation for inadequate physical planning or regulation." (Weaver, 1998, p.302)
\end{abstract}

As indicated by Jordan $(2004,2007)$, despite the fact that the constitution guarantees the existence of the Tobago House of Assembly, central government dictates tourism policy for Tobago as well as the size of budgetary allocations for the island, which it may be argued will and has influenced the pace of tourism development. The absence of consistent communication, cooperation, consultation and collaboration further worsens the situation and has resulted in the slow, sporadic growth of Tobago's tourism industry. As stated by a Trinidad and Tobago based British Broadcasting Corporation (BBC) Caribbean reporter Fraser

\begin{abstract}
"Tobago was the heart of the twin-island republic's tourism industry; yet, tourism policy and funding is controlled by the central government in Trinidad. Where you have a Secretary for tourism in Tobago, dictates still come from Trinidad with regard to tourism policy and the funding of tourism development so that's one really crazy part of the administration." (Fraser, 2005)
\end{abstract}

Perhaps, the issue of dual governance is a cause of the state of tourism development on the island of Tobago. As argued by Jordan

\begin{abstract}
"It means that in effect, both the THA and the Central Government have the authority to develop and implement tourism policy for Tobago and undoubtedly, this has caused many conflicts and misunderstandings to occur between TIDCO, the Ministry of Tourism and the THA." (Jordan, 2007, p.18)
\end{abstract}

\title{
4 Research method
}

Two research questions were examined: How tourism policy influences tourism development in the small twin-island state of Trinidad and Tobago?, and How an arrangement of dual governance in a small twin-island state promotes tourism development?. As a result of the exploratory nature of the study, interviews were utilised as the prime source of data. Scott cites Burgess's (Scott and Usher, 1996) three reasons for using interviewing as a main data collection method. These reasons are access to past events, access to situations at which the researcher was not present and access to situations where permission was refused. Researchers have noted that there are social activities outside the consciousnesses of individuals that make the interview process not absolute. Nonetheless, Giddens cited in Scott and Usher (1996) argues for interpretative research based on the double hermeneutic framework. This hermeneutic framework 
provides for reflectivity, which nullifies any discrepancy. Thereby, a balance occurs since interpretation of the social activity involves both conceptual and perceptual means, making the process valid. The interview method was also used since, as Clark et al. argue

"the interview as a form of research and a method of collecting qualitative data is at its most useful when it gives us insight into how individuals or groups think about their world, how they construct the 'reality' of that world." (Clark et al., 1998, p.132)

The primary research involved a non-probability or convenience sample of 26 face-to-face interviews since as Sekaran argues

\begin{abstract}
"the main advantage of face-to-face or direct interviews is that the researcher can adapt the questions as necessary, clarify doubts, and ensure that the responses are properly understood, by repeating or rephrasing the questions." (Sekaran, 2003, p.232)
\end{abstract}

Interviewees included politicians and members of tourism boards, hoteliers, ground tour operators, tourism advisors, research officers and representatives of non-governmental organisations. Seventeen were Tobago-based and nine Trinidad-based, 18 were from large organisations and eight from small organisations. The majority of respondents, 15 , were from the public sector. The mix of interviewees from different sectors, different sized organisations and from the different islands contributed to concurrent and sampling validity, reliability and representativeness, although it is acknowledged that the sample was nevertheless relatively small. The interviews were taped.

As suggested by Ritchie and Spencer (1994, p.176), "qualitative data analysis is essentially about detection, and the tasks of defining, categorizing, theorizing, explaining, exploring and mapping are fundamental to the analyst's role". Thus, the content analysis method of qualitative research was used to analyse the interview data. As pointed out by Neuendorf (2002, p.15), "content analysis summarises rather than reports all details concerning the message set". As a result, textual data were summarised and later categorised by island and sector using a Microsoft Excel spreadsheet. Distinctions were made and similarities and differences among themes emerged. Berg (1998) suggests that a theme is a useful unit of analysis. Therefore, the analytical technique involved making thematic distinctions from summarised content. Krippendorff (1980, p.110) suggests that obtaining thematic distinctions "preserves the richness of textual interpretations". The thematic content formed the basis for examination of the research questions.

\title{
5 Results
}

The interview data are summarised from a case study conducted by McLeod (2005) on "Politics and Tourism in Tobago". Some quotations are summarised, other quotations are placed in quotation marks and the interviewees' categories are placed in parentheses. A general overview of the state of tourism development was first examined and interviewees' opinions on the link between tourism policy and tourism development in Tobago were explored. Thereafter, the tourism development effectiveness of the two governments was considered and the issue of dual governance and its impact on tourism policies influencing tourism development was analysed. 
On average, interviewees had 17 years tourism industry experience ranging from 47 years at most to three years at least. Generally, they noted that an absence of political will and of policy instruments such as planning and legislation had affected tourism development with the result being unplanned tourism development. The respondents argued that government should have a clear mandate as to how the tourism industry should proceed. While interviewees in Trinidad viewed policies affecting tourism being related to planning issues, the interviewees in Tobago were more concerned about the policies benefiting the people (a divergent view). Over the period 2002-2004, tourism's share of GDP has almost doubled in Tobago from $27 \%$ in 2002 to $46 \%$ in 2004. Employment has increased from 7,000 persons to 15,000 persons over the same period. As a result, tourism now employs $60 \%$ of the workforce in Tobago (Tobago, Public Sector). Tourism has brought more opportunities to local people who offer a range of services to facilitate tourists and several homes have expanded to offer guest rooms and food and beverage services. One respondent expressed concern that this will create a 'tourist trap' and emphasised the need for maintaining the ambience of the village community (Tobago, NGO).

The question about main policies influencing tourism development in Tobago was asked to examine the perceived relationship between tourism policy and tourism development. In relation to this, interviewees generally believed that there is no explicitly stated tourism policy for Tobago. Furthermore, they (Tobago, Public Sector) argue that tourism policy is not working since there has been no major private investment in the industry. A legislative initiative through the Tourism Development Act (TDA) of 2000 possibly influenced what activity has occurred but there seems to be little promotion of this Act. One interviewee (Trinidad, Public Sector) recommended that there is a need for a broad policy encouraging tourism. Another indicated that the existence of no vision or policy has resulted in no distinctive feature of tourism development in Tobago. The "Tobago thing seem to be anything; a license to do anything" (Tobago, Private Sector). Interviewees stated that the government has attempted to influence development on the island through tourism policy. This may be because tourism is seen as being important in Tobago since there is simply no other economic driver. One respondent saw that there is no particular policy and that tourism development is market-driven (Tobago, Private Sector). Another respondent (Tobago, Public Sector) stated that the overarching tourism policy is one of a commitment to maintaining the integrity of the environment. One respondent (Trinidad, Public Sector) mentioned that international companies such as TUI are perhaps more powerful in formulating policy locally.

On the question of the Tobago House of Assembly's role in the development and implementation of tourism policy on the island, many interviewees indicated that the THA is the lead body ensuring that stakeholders, and in general Tobagonians, benefit from tourism. The THA's role is critical since central government do not see tourism as a priority (Trinidad, Public Sector). As one respondent articulated, "all local government organisations should have direct responsibility to handle tourism matters ... It is not just Tobago, it is the whole country" (Trinidad, Public Sector). Additionally, the THA should facilitate stakeholders and assist with approvals to expedite investment applications. Notably, one respondent suggested that the THA could develop policy for tourism in Tobago that does not have to be synchronised with central government policy (Trinidad, Public Sector). The basis of this is the differing tourism products. While some interviewees in Trinidad and Tobago both agree that central government has a role in the development of tourism policy, since the country is a twin-island state, there is 
widespread agreement that the implementation of tourism policy is the THA's role. Some interviewees from the Tobago Private Sector strongly advocated the view that central government should not have a role in the development of tourism policy on the island of Tobago. The reason for this relates to self-determination and mistrust. The major problem affecting the THA's effectiveness is its dependency on Trinidad for funds and the associated conditions as to how the funds are used, because in practice the THA does not have effective autonomy. A recommendation was made for continued effectiveness by allowing Tobago to collect its own taxes and being empowered to spend this.

When it comes to central government, some interviewees believe that the jurisdiction to promote tourism resides in TIDCO (another former national tourism organisation of central government), which fell under the Ministry of Tourism, and those policies of TIDCO and THA should be synchronised for effectiveness. There are perceptions of agency encroachment and personality problems that may impact upon such synchronisation. On the question of the effectiveness of central government policy actions in promoting tourism development, interviewees generally noted that central government has played a minimal role in the development of tourism in Tobago. Central government's role has been

- acting as a body that ratifies and sanctions decisions

- funding tourism, though more emphasis is placed on the petroleum industry and light manufacturing

- seeking to give Tobago autonomy through the Tobago House of Assembly Act of 1996

- passing of the Tourism Development Act of 2000; and no clear-cut national tourism policy.

Central government's ineffectiveness was evidenced by statements like

"I don't think they [central government] are promoting tourism development (Trinidad, Private Sector); and 'quite sure that the majority of central government is not appreciative of the value of tourism because in an oil based economy tourism is played down (Tobago, Public Sector)."

Respondents believed that Tobago is in the best position to monitor tourism and that the THA have more of an idea what they want to do. Nevertheless, the allocation of funds to tourism projects is not significant. On the part of central government, respondents stated that central government does things without consultation and is unsynchronised and as a result there is no serious, consistent execution. There was a belief that central government is not motivated to develop tourism since the majority of GDP does not come from tourism.

Conversely, those interviewees who indicated that central government was effective stated that there was a broad-based collaborative approach; there was more funding and a good and healthy collaboration between Minister of Tourism and Secretary of Tourism, THA. Interviewees also mentioned that tourism only works when the political party in power is the same in both islands.

On the question of whether the policy actions of the THA are different from those of central government and whether there are policy conflicts, interviewees identified that there are conflicts 
- legislative interpretation by the implementers

- difference of views since the THA has consultation with industry and central government does not

- emphasis of Trinidad is the oil industry

- market and economic differences

- Trinidad giving final approval for investment projects in Tobago

- disagreement on areas requiring Environmental Impact Assessment (EIA).

An example was given of a former THA administration wanting small-scale community tourism development whereas central government wanted grand-scale development. Moreover, the way government for the twin-island state is configured brings a measure of conflict. The Cabinet is responsible for everything in both Trinidad and Tobago. Therefore, Ministries may not want to come to terms with the fact that the THA has the authority to undertake development and administration of certain portfolios; though having one political directorate does help to reduce the conflict. Nevertheless, those interviewees who do not see any policy conflict identified clearly that central government should be responsible for marketing and the THA product development; the THA should be allowed to fund projects; there should be an indigenous created policy that suits Tobago; and, the conflict has to do with prioritising rather than policy-making. Interviewees who agreed that dual governance has affected the formulation of tourism policy, and thus tourism development, felt that the main weaknesses were:

- the situation is not a reliable one since there may be different political parties

- overlapping jurisdiction, blurred roles and responsibilities resulting in duplication and lack of collaboration

- distinct geographical entities with actors encroaching in each others' domain

- difference in level of importance of the tourism industry

- the THA decides while funding comes from Trinidad

- the intervention of an opposition party making political objections

- instead of being cooperative, there is conflict and controversy

- duality resulting in a lack of accountability

- Minister having final say, frequent changing of Ministers and Ministers holding on to 'own space'

- institutions set up did not operate to the benefit of the people of Tobago.

Those interviewees indicating that dual governance is not affecting tourism development stated that

- there was representation from the THA advancing the Assembly's views

- it should not affect it since Trinidad and Tobago should show a joint front overseas 
- same political party eases the situation

- it does not affect it since there is nothing that Tobago does that Trinidad does not allow

- dual governance works for Tobago since Tobago is clear on its 'bread and butter' it does not work for other parts of Trinidad.

To resolve the conflict issues of dual governance, recommendations were made for

- autonomy

- clarification of lines of communication

- sustainable political relationship through federalisation of Tobago to allow the THA to raise and fund own initiatives

- tourism development should not be left to politics and if and when a political party changes, there should be maturity to see the importance of tourism to the economic and social development of the island.

\section{Discussion}

Overall, interviewees were of the view that dual governance has affected tourism policy's influence on tourism development. The effect of dual governance is evident by the relatively constrained growth of tourist arrivals in Tobago when compared with other Caribbean tourism destinations. Interviewees agreed that the THA is effective in promoting tourism development. However, dependency for funds from Trinidad is a constraint. On the other hand, central government has been deemed ineffective in promoting tourism development. There is seemingly a lack of motivation to develop tourism, perhaps since oil is the economic driver of Trinidad. As a result, there are policy conflicts. Such conflict is quelled, however, when the same political party on both islands is in power. Nevertheless, tourism policy made in a framework of dual governance does not appear to have permitted the most effective development of tourism.

Generally, the tourism industry seems to be in an environment that does not allow for proper policy formulation and action, an issue addressed by several authors (Hall, 1994; Dredge and Jenkins, 2003a, 2003b; Kerr, 2003). Evidently, tourism policy is not well formulated (Edgell, 1999; Bramwell and Sharman, 1999) in a framework of dual governance and as a result, tourism development in Tobago has not been to its fullest potential. In other words, tourism in Tobago has not been on a smooth path of development early in its life cycle (Butler, 1980). Goals may be set, but these are not achieved since policies are not well formulated to do so or the strategies adopted are constrained (Mill and Morrison, 1985). Certainly, the Chambers and Airey (2001) argument, which states that government's public policy position impacts tourism development holds. As indicated by interviewees, the advent of the same political party governing both islands was seen as affecting tourism development. Thus, oneness of ideology, with the same political party ruling both islands, has resulted in a new pattern of tourism development in Tobago. 
Mill and Morrison's (1985) model clearly outlines how a tourism policy framework can influence tourism development. The initial stage is the identification of the broader needs, which is arguably done effectively by the government on the ground. Thereafter, policies are developed to achieve these goals. After the policy stage, strategies are implemented that will affect the tourism product. In Tobago's case, the tourism policy process was met with constraints, which have delayed the achievement of goals. Seemingly, the phenomenon of dual governance is a plausible explanation. In addition, based on the argument that industry cannot survive without government (Kerr, 2003) and in particular central government's motivational stance on developing a tourism industry based on public policy, over a period of more than 50 years, tourism in Tobago seemed to have developed slowly. Tourism policies were not well formulated to affect tourism development in Tobago.

In addition, there is the issue of the Minister of Tourism giving final approval for projects in Tobago, which relates to planning activity (planning as an instrument was mentioned by several interviewees). Ministerial approval of projects in Tobago has been an untenable situation. The question is whether a central or national planning platform is necessary. Hall and Jenkins (1995) argue that a central platform is difficult since groups may not work together as a result of the reduction in power through collaboration. In light of the need for planning tourism development (Gunn, 1988; Hall, 2000), the development of the Tobago tourism industry based on a localised focus, rather than a national plan, is more practical. As indicated by the findings of this study, central government will not be motivated in the formulation and implementation of tourism policy in Tobago since tourism does not drive the economic environment of central government based in Trinidad. Thus, it is more effective to formulate and implement tourism policy at the local level. According to Dredge and Jenkins (2003a), the state must re-work its policy position and support local and regional organisations. Tourism development is constrained when responsibilities for tourism development remain scattered (Church et al., 2000). Thus, there is need to review the system of governance in a twin-island state scenario with two different economic drivers, one an oil industry and the other based on tourism.

\section{Conclusion}

This study clearly reveals particular circumstances under which tourism development, based on a policy framework, is constrained. In the case of Tobago, the tourism industry's development has been slow as a result of tourism policy not being well formulated and implemented. While government intervention is necessary to develop tourism, such intervention becomes challenged by a dual governance arrangement. Based on the complexity of issues and interests, which form the basis of tourism policy-making, dual governance complicates matters. This research study argues for tourism policy-making at the local level, which would be different from that at the national level, particularly since each island has a different economic driver.

The limitations of this research relate particularly to the fact that it took place at a time when the same political party had been in power in both islands for some time. Hence, it was not possible to explore the effects of political divergence in this dual governance structure. This could be a useful topic for a study in the future. 
It also happened to coincide with a period when there was a significant growth in visitor arrivals, although there was no evidence that this was related to tourism policy changes.

As nations join together, one wonders how policy formulation and implementation among governments will occur. This research study contributes to a better understanding of the role of sub-national government policy actions to influence economic development, particularly those relating to tourism. Specifically, this study has contributed to the knowledge on political aspects involved in the development of the tourism industry in a Caribbean Island State.

\section{Acknowledgements}

The authors thank Dr. Jonathan Edwards and Professor Roger Vaughan of Bournemouth University for their helpful suggestions and comments. Special thanks are due to the 26 interviewees who took time to answer the research questions.

\section{References}

Berg, B.L. (1998) Qualitative Research Methods for the Social Sciences, 5th ed., Allyn \& Bacon, Boston.

Bramwell, B. and Sharman, A. (1999) 'Collaboration in local tourism policymaking', Annals of Tourism Research, Vol. 26, No. 2, pp.392-415.

Butler, R.W. (1980) 'The concept of a tourist area cycle of evolution; implications for management of resources', The Canadian Geographer, Vol. 24, No. 1, pp.5-12.

Caribbean Tourism Organisation (CTO) (2005) Unpublished Data from the Annual Tourism Statistical Report, CTO, Barbados, http://www.onecaribbean.org/information/ categorybrowse.php?categoryid=205, Accessed 3.07.07.

Central Statistical Office (CSO) (2005) Unpublished Data from the Travel and Tourism Statistics, CSO, Trinidad and Tobago, http://www.cso.gov.tt/statistics/indicators.aspx, Accessed 3.07.07.

Chambers, D. and Airey, D. (2001) 'Tourism policy in Jamaica: a tale of two governments', Current Issues in Tourism, Vol. 4, Nos. 2-4, pp.94-120.

Church, A., Ball, R., Bull, C. and Tyler, D. (2000) 'Public policy engagement with British tourism: the national, local and the European Union', Tourism Geographies, Vol. 2, No. 3, pp.312-336.

Clark, M., Riley, M., Wilkie, E. and Wood, R.C. (1998) Researching and Writing Dissertations in Hospitality and Tourism, Thomson, London.

Cooper, C., Fletcher, J., Gilbert, D. and Wanhill, S. (1998) Tourism Principles and Practice, Pearson Education Limited, England.

Curtin, S. and Busby, G. (1999) 'Sustainable destination development: the tour operator perspective', International Journal of Tourism Research, Vol. 1, No. 2, pp.135-147.

Department of Tourism (DOT) (2005) Unpublished Data from Tobago Tourism Statistics, DOT, Tobago House of Assembly, Tobago.

Dredge, D. and Jenkins, J. (2003a) 'Destination place identity and regional tourism policy', Tourism Geographies, Vol. 5, No. 4, pp.383-407.

Dredge, D. and Jenkins, J. (2003b) 'Federal-state relations and tourism public policy, New South Wales, Australia', Current Issues in Tourism, Vol. 6, No. 5, pp.415-443.

Edgell, D.L. (1999) Tourism Policy: The Next Millennium, Vol. 3, Champaign, Sagamore, USA. 
Fraser, A. (2005) British Broadcasting Corporation, Caribbean News Story, http://www.bbc.co.uk/ caribbean/news/story/2005/01/050104_tobagoelections-analysis.shtml, Accessed 02.05.

Gunn, C.A. (1988) Tourism Planning, 2nd ed., Taylor \& Francis, New York.

Hall, C.M. (1994) Tourism and Politics: Policy, Power and Place, John Wiley \& Sons Limited, England.

Hall, C.M. (2000) 'Rethinking collaboration and partnership: a public policy perspective', in Bramwell, B. and Lane, B. (Eds.): Tourism Collaboration and Partnerships: Politics, Practice and Sustainability, Channel View Publications, Clevedon, pp.143-158.

Hall, C.M. and Jenkins, J.M. (1995) Tourism and Public Policy, Routledge, London.

Jenkins, C.L. (1991) 'Tourism development strategies', in Bodlender, J., Jefferson, A., Jenkins, C. and Lickorish, L. (Eds.): Developing Tourism Destinations, Policies and Perspectives, Longman, Harlow, pp.61-77.

Jordan, L. (2004) 'Institutional arrangements for tourism in small twin-island states of the Caribbean', in Duval, D.T. (Ed.): Tourism in the Caribbean: Trends, Development, Prospects, Contemporary Geographies of Leisure, Tourism and Mobility, Routledge, London, pp.99-118.

Jordan, L. (2007) 'Interorganisational relationships in small twin-island developing states in the Caribbean - the role of the internal core-periphery model: the case of Trinidad and Tobago', Current Issues in Tourism, Vol. 10, No. 1, pp.1-32.

Kerr, B., Barron, G. and Wood, R.C. (2001) 'Politics, policy and regional tourism administration: a case examination of Scottish area tourist board funding', Tourism Management, Vol. 22, No. 6, pp.649-657.

Kerr, W.R. (2003) Tourism Public Policy, and the Strategic Management of Failure, Pergamon, Elsevier Limited, UK.

Krippendorff, K. (1980) Content Analysis - An Introduction to its Methodology, Sage Publications, London.

Matthews, H.G. and Richter, L.K. (1991) 'Political science and tourism', Annals of Tourism Research, Vol. 18, pp.120-135.

McLeod, M.T. (2005) Politics and Tourism in Tobago, Thesis (MSc), University of Surrey, UK.

Mill and Morrison (1985) The Tourism System: An Introductory Text, Prentice-Hall International, London.

Neuendorf, K. (2002) The Content Analysis Handbook, Sage, Thousand Oaks, California.

Pearce, D. (1989) Tourist Development, Longman Group UK Limited, England.

Pearce, D. (1996) 'Regional tourist organizations in Spain: emergence, policies and consequences', Tourism Economics, Vol. 2, No. 2, pp.119-136.

Richter, L.K. (1985) 'Fragmented politics of tourism', Tourism Management, Vol. 6, No. 3, pp.162-173.

Ritchie, B.J.R. and Crouch, G.I. (2003) The Competitive Destination: A Sustainable Tourism Perspective, CAB International, UK.

Ritchie, J. and Spencer, L. (1994) 'Qualitative data analysis for applied policy research', in Bryman, A. and Burgess, R.G. (Eds.): Analyzing Qualitative Data, Routledge, UK, pp.173-194.

Sautter, E.T. and Leisen, B. (1999) 'Managing stakeholders a tourism-planning model', Annals of Tourism Research, Vol. 26, No. 2, pp.312-328.

Scott, D. and Usher, R. (1996) Understanding Educational Research, Routledge, London.

Sekaran, U. (2003) Research Methods for Business: A Skill Building Approach, John Wiley \& Sons Inc., USA.

Sharpley, R. and Telfer, D.J. (Eds.) (2002) Tourism and Development: Concepts and Issues, Channel View Publications, UK. 
Trinidad and Tobago Tourism Development Authority (TDA) (1988) Tourism Policy, Unpublished document from the TDA, Trinidad and Tobago.

Tyler, D. and Dinan, C. (2001) 'The role of interested groups in England's emerging tourism policy network', Current Issues in Tourism, Vol. 4, No. 2, pp.210-252.

Weaver, D. (1998) 'Peripheries of the periphery: tourism in Tobago and Barbuda', Annals of Tourism Research, Vol. 25, No. 2, pp.292-313.

Weaver, D.B. (1981) Tobago: The Spatial Development of a Caribbean Tourist Industry, Wilfrid Laurier University, Canada. 